\title{
Limited growth opportunities amidst opportunities for growth: an empirical study of the inter-firm linkages of small software firms in India
}

Vigneswara P llavarasan ${ }^{1 *}$ and Balaji Parthasarathy ${ }^{2}$

\begin{abstract}
Small firms are important to all economies. This is especially true with the rise of the information and communication technologies (ICTs), as the technical characteristics of information goods lower entry barriers for small firms seeking to take advantage of the growing global demand for ICTs. However, for accessing global markets, or for technological learning, the literature points to the potentially important role of intermediary institutions. This paper examines inter-firm linkages in India, the world's largest exporter of software services, to explore the extent to which large software firms, both foreign multinational corporations (MNCs) and domestic firms, play an intermediary role for the growing number of small firms. Drawing on 172 in-depth, semi-structured interviews, the paper finds that linkages between the large and small firms are few and weak. MNCs prefer working with large domestic firms as they seek the scale to cut costs for labor-intensive services. Large domestic firms too tend not to outsource work to small firms. They prefer independent execution, viewing small firms as potential competition. Any inter-firm links are typically limited to labor contracting and rarely provide access to markets or opportunities for technological learning. Thus, lacking the operational scale, technological or domain diversity, small firms end up dependent on personal networks to access global market opportunities, i.e., despite the growth in opportunities provided by ICTs, the growth opportunities for small software firms in India remain circumscribed.
\end{abstract}

Keywords: Inter-firm linkages, Small software firms, Information and communication technologies, Indian software industry

\section{Background}

The economic contribution of small firms to industrially developed and developing countries is widely recognized (Ayyagari et al. 2007). For instance, in the Organisation for Economic Co-operation and Development (OECD) countries, small and medium firms contributed to more than two-thirds of all private employment, and $58.4 \%$ of the total gross-value added produced by private businesses, in 2010 (Commission 2010). Thus, countries increasingly pursue policies to promote small firms to attain various goals such as employment generation, innovation, and entrepreneurship.

\footnotetext{
* Correspondence: p.vigneswara@iimrohtak.ac.in

${ }^{1}$ Indian Institute of Managem ent Rohtak, MD Univ. Campus, Rohtak,

Haryana 124001 , India

Full list of author information is available at the end of the article
}

In the era of mass manufacture, small firms typically played supporting roles, such as subcontracting to large firms. However, in the information and communication technology (ICT) industry, small firms are able to compete with large firms by innovatively adapting to rapid technological changes (Ba et al. 2000) and meeting the demands of niche markets (Lerner 2000). This is due in part to market opportunities offered by the growing global demand for software which increasingly determines the cost and functionality of all ICT products (Parthasarathy 2010). The growth in demand is a result of the proliferation of increasingly less expensive and more powerful ICTs in various domains of economic activity.

There are certain characteristics of ICTs which also set them apart from other manufacturing (Baetjer 1998). For instance, the mass production of software is not 
subject to decreasing returns to scale. After development, the cost of reproducing software is near zero and the cost declines with every additional user, thus resulting in increasing returns to scale. Besides, the electronic distribution of software products is less expensive than shipping physical goods. With relatively low capital requirements to establish firms, and rapid technological obsolescence, the software industry offers market opportunities for both new and small, and well-established and large firms by lowering entry barriers. ${ }^{\text {a }}$

Alongside the growth in demand for mass-produced software, the demand for labor-intensive custom software has also grown (Arora 2005). The growing demand for customized software services has led to a shortage of skilled labor in developed countries. This shortage is met either by attracting skilled, but relatively low cost, labor from developing countries or by outsourcing work to them. Although the outsourcing was mostly limited to relatively low-skill activities in the 1980s and the early 1990s, there is a growing trend toward outsourcing more skill-intensive work (Arora 2005; Parthasarathy and Aoyama 2006). As these global opportunities, for supplying labor directly and for outsourced work, are increasingly sources of revenue and employment, the ICT industry has become an engine of economic growth for at least those developing countries with the necessary human capital (Arora 2005; Parthasarathy 2010).

Arguably, no developing country took as much advantage of the rising demand for software services as India which, by 2000, became the largest software exporter among non-OECD countries (OECD 2002). This paper empirically investigates how small software firms in India have fared amidst these opportunities. It will argue that, although there has been a rapid increase in the number of small firms, the absence of strong, supporting intermediary institutions, especially inter-firm linkages, has inhibited their growth. In other words, despite the growth in opportunities for the Indian software industry, the growth opportunities for small firms are circumscribed by weak inter-firm linkages.

The paper is divided into five sections. Following the background presented in this section, the next section discusses the importance of intermediary associations and how small firms might access global market opportunities; the third section introduces the Indian software industry and argues why small software firms, especially in India, need intermediary institutions; the fourth section discusses the inter-firm linkages of small firms in India; the fifth section concludes the paper by highlighting the key findings; and, finally, the sixth section explains the methodology used by the study.

\section{Inter-firm linkages as an intermediary institution}

While the characteristics of ICTs and the growth of global markets have conferred significant advantages on small entrepreneurial firms on the supply (production) side, research in developed countries highlights the importance of intermediary institutions for linking new, entrepreneurial ICT firms and global opportunities. Small firms often find the cost of commercializing innovative ideas and competing in the global market unaffordable (Commission 2011 They are also limited by inadequate access to market information and to marketing expertise. Intermediary institutions can fill this void. These institutions take various forms in different contexts and act either independently or together. They include venture capital (Torres and Murray 2003), personal networks (Bell et al. 2004; Davis and Sun 2006; Ojala 2009), the state and the policy environment (Bell et al. 2003; Casper and Whitley 2002; Saxenian 2006), science and technology parks (Heeks and Nicholson 2002; Lindelof and Lofsten 2003), and trade associations (Bennett and Ramsden 2007). This paper focuses on inter-firm linkages.

For small export-oriented firms, the linkage with other firms is indispensable in nurturing or exploiting opportunities (Coviello and Munro 1997; Kennedy and Keeney 2009; McNaughton 2002; Yli-Renko and Tontti 2002). The literature on the internationalization of firms highlights the role played by multinational corporations (MNCs) in providing global access to small firms (Bell 1995; Prashantham and McNaughton 2006). MNCs played a significant role in the development of the industry in Ireland (Arora et al. 2001) and in China (Vang and Ashiem 2006). Small firms benefit from their linkages with large firms, as 'highly innovative SMEs [small and medium enterprises] might be better off by leaving the internationalization of their innovations to MNEs [multinational enterprises] and sharing some of the international direct exporting profits with them instead.' (Acs et al. 2001, page 235).

However, the need of small firms to use larger firms to access global markets must be matched by the willingness of the latter to play the role of intermediary institutions. Gomes-Casseres (1996)) argues that the size of the firms relative to their competitors is important in determining the alliances between firms. Alliances are decided by three factors: the capabilities of the firms, the control of the firm in using and deploying the capabilities in the alliances, and the context that demands alliances. Castellani and Zanfei (2002)) indicate that MNCs tend to collaborate with local firms in industries characterized by 'fast learning and extensive knowledge exploitation opportunities' (page 20). Also, 'acquaintance with local context enhances foreign firms' capacity to select, and interact with, local partners and institutions, as a means of gathering further stimuli and innovative ideas, and of exploiting effectively opportunities emerging from local contexts' (page 20). 
When large firms, whether MNCs or domestic firms, do not find it advantageous to play the role of intermediary institutions, small firms are forced to seek other options to access the global market. However, existing research, on the role played by intermediary institutions in accessing global markets, is predominantly focused on developed countries. Given the importance of small software firms in developing countries, the need to examine them cannot be ignored. Despite the vast literature on the ICT sector in developing countries' research on small software firms is limited and we do not know how export-driven small software firms in developing countries survive, and if and how they access global opportunities. The present paper fills this gap using the case of the Indian software industry.

\section{The need for intermediary institutions in the Indian software industry}

India became the largest software exporter among nonOECD countries by 2000 mostly by providing laborintensive, custom software services (Parthasarathy 2004). The revenues of the Indian ICT services industry grew from US $\$ 7.8$ billion in 2001 to US $\$ 88.1$ billion in the financial year 2011, with two-thirds coming from exports (NASSCOM 2012a). Amidst this growth, there was a rapid increase in the number of small firms largely due to the dismantling of regulatory barriers for the software industry since the mid-1980s (Parthasarathy 2004). This increase is substantiated by data from the National Association of Software and Service Companies (NASSCOM), a trade association, whose membership accounts for $95 \%$ of industry revenues (NASSCOM 2012a). The number of NASSCOM members grew from 131 in 1991 to 1992, to 810 in 2000 to 2001, to 1,250 in December 2010 (NASSCOM 2012b). The period for which the firm-level data is available showed that the median firm size, as measured by the number of technical employees, declined from 100 in 1994 to 1995 to 73 in 1999 to 2000, suggesting the entry of a large number of relatively small firms in this period. ${ }^{\mathrm{b}}$

Yet, while the number of firms grew more than sixfold, 'the (twenty) top firms in the industry continue to grow at a scorching pace with the trend rate of growth till 2007-08 amounting to $34 \%$ per annum whether we take 1991-92 or 2001-02 as the base year' (Chandrasekhar 2008). In 2011, twenty firms contributed to $64 \%$ of total industry revenues (Dataquest 2012). This not only indicates continued dominance by large firms, but it is also not clear how the growing numbers of small firms survive.

Existing studies of the Indian software industry investigate the industry as a whole without differentiating small firms from the others. The studies that focus exclusively on small firms (for example, Morris et al. 2001) in India do not recognize the existence of small software firms adequately. Since any existing information about small software firms in India is mostly from the trade press, there is a need for a systematic empirical study of small software firms in India.

The available literature shows that between the mid80 s and the mid-90s, small software firms could access global markets to grow by resorting to bodyshopping, or the practice of providing inexpensive on-site (i.e., at customer locations overseas) labor on an hourly basis for low-value added programming services (Parthasarathy 2004). During the 1990s, bodyshopping gave way to offshore development (i.e., software development in India for global customers) once Indian firms had built up their reputation and had access to reliable data communication infrastructure at the Software Technology Parks (STPs) that were established by the government. This was how many small firms which were established in the 1980s grew to become large exporters. A case in point is Infosys which was established in 1981 by seven professionals with US $\$ 250$ as capital and grew to US $\$ 414$ million in revenues two decades later to become India's second software largest exporter (Infosys 2012).

But the window of opportunity enjoyed by firms such as Infosys began to close from the mid-1990s due to growing labor market pressures (Parthasarathy 2004). Having gained a favorable reputation since the 1980s, the Indian software professional no longer depends only on employment opportunities in India. In the 1990s, a worldwide demand for skills drew Indian professionals in increasing numbers to lucrative opportunities overseas. Just one indicator of this phenomenon was that Indians became the largest beneficiaries of the US H1-B visa program, and, later, the L1 program too. ${ }^{\mathrm{C}}$ These programs were established to permit the employment of workers with 'specialized knowledge' and have been used extensively by the advanced technology sector. As the Indian labor market for software professionals and the global labor market were no longer distinct universes, wages in India started to rise. This especially affected capital-strapped small entrants to the industry who could no longer rely on low wages to enter the global market. It is against this backdrop that intermediate institutions have a critical role to play.

Studies of the Indian software industry suggest that intermediary institutions play a limited role. The dismantling of regulatory barriers by the state has not been accompanied by an active promotional role, with the exception of the establishment of the STPs from the early 1990s. Small software firms are yet to receive due acknowledgment from the state. Policy-making committees or bodies typically represent the interests of the larger companies. For instance, during the period of study, there was no representation for small ICT firms in any advisory committee established by the Government of India's Ministry of Information Technology (Aggarwal 2002). 
The Indian state also has been less aggressive in enticing back highly skilled migrants or in enhancing brain circulation, unlike China and Taiwan (Saxenian 2006). Despite the professional and entrepreneurial success enjoyed by the Indian expatriate community in Silicon Valley, they have not contributed to building ties between domestic firms in India and global markets to the extent that their Chinese or Taiwanese compatriots have. In other words, Indian firms have been able to rely less on social networks for foreign market access than Chinese or Taiwanese firms.

Although NASSCOM is considered successful in lobbying with the government and in branding the Indian software industry in external markets (Kanavi 2004), trade press reports suggest that the association favors large players (Srikanth and Glancy 2003). Despite its establishment in the late 1980s, it was only during 2002 that NASSCOM started a small and medium enterprises forum, with workshops and lectures to specifically address the needs of small firms (NASSCOM 2002), but the effectiveness of these initiatives is unclear.

Venture capital is not well developed in India either, and the policy environment is not as supportive as in other countries. Further, existing venture capitalists prefer to finance established large firms rather than small entrepreneurial firms (Dossani and Kenny 2002). Similarly, Teubal (2002)) argues that 'domestic venture capital industry with characteristics similar to those of US and Israel' (page 180) are unavailable in India.

Research on MNCs in India indicates an overall positive impact on the local industry. The rise of India as a region for software services development is attributed in part to the successful demonstration by the India centers of MNCs like Texas Instruments and Motorola. As Balakrishnan explains:

'Multinationals played a dual role of providing invaluable 'domain knowledge' to Indian firms that wrote customized software for them and served as impresario [sic] when these firms sought to launch themselves on the international market.' (Balakrishnan 2006, page 3871).

Patibandla and Petersen (2002)) add that the presence of foreign MNCs has resulted in human capital accumulation and evolution of the industry through technological upgrading. Athreye (2002)) points out that the offshore business model mastered and followed by the local firms was first introduced by the early MNCs in India. Vang and Ashiem (2006)) credit the building of Bangalore as a software service region to the presence of MNCs and their strategic linkages with various actors in the region.

However, other arguments suggest that foreign MNCs played more of a demonstration role than offering linkages to global markets. For instance, according to Balasubramanyam and Balasubramanyam (1997) the 'Indian software sector is an "export enclave" which enables it [the MNC] to earn high private rates of return to investment, may serve to misallocate valuable human capital in the economy' (page 1860; see also D' Costa 2003). Similarly, a study of the Bangalore cluster by Rasmus and Hesbjerg (2003) suggests that Indian firms operate as virtual extensions of their clients abroad and, consequently, lack inter-firm linkages in India. Nevertheless, there is little research to differentiate between large and small firms. An exception is the study by Chaminade and Vang (2008) which emphatically states, 'only a small group of firms has benefited from the interaction with the TNCs [MNCs]' (page 1691) in the Bangalore cluster in the interaction between SMEs and multinationals. However, since this observation is not supported by any evidence, we do not know whether and how small firms benefited from the presence of MNCs.

Large domestic firms are also known to be the sources of new firm formation. Anecdotes of employees leaving to found their own firms abound. For instance, a trade press survey showed that at least 270 firms were founded by people leaving just two of India's largest exporters, Wipro Limited and HCL Technologies (Vishwanathan 2001). More recently, NASSCOM's Vice President was quoted by the Economic Times (2011) as having claimed that 'there are some 1,600 tech start-ups in the country and about $80 \%$ of them are being launched by experienced IT employees, working in India and overseas.' Once again, it is unclear if and how small firms use their previous employers as intermediaries to access global markets.

\section{Results and discussion}

\section{The operational strategies of MNCs}

Although $55 \%$ of the sample firms reported MNCs as collaborators, inter-firm linkages mostly involve large domestic firms and MNCs rather than small firms. Linkage with large domestic firms is established through two ways: one is through 'independent software vendor' (ISV) programmes, and the other is through the establishment of an India Development Center (IDC).

In the ISV programme, a MNC encourages local firms to develop products or services that serve as supplement to its offerings. ISV partners are identified by a formal selection mechanism and provided infrastructure, such as software and hardware, at lower than market prices. They are also given limited technical support. MNCs claim that they are not partial to either small or large domestic firms. According to the MNCs, the opportunity to become an ISV is open to anybody with the necessary capabilities. To quote from an interview with an MNC:

'We are not strict in partner inductions. They should be developers. They should be serious. They should not be misusing the technology we offer. Our partners include everybody, SMBs (small and medium businesses), and larger players like Iflex, Wipro, 
Pramati, etc. We do not really look at size. We look at the development capabilities. For us, everybody is the same. We need to see their potential and the potential for our products. There is no difference between small and larger players in treatment.'

However, when MNCs were asked to list collaborating firms, they were typically the names of prominent larger players that were mentioned. Rarely did they name smaller firms. One MNC reasoned that, since they were new to India, they would like to collaborate with established, larger firms initially before working with smaller firms. Moreover, only larger firms are able to meet the requirements of the ISV programme.

Although MNCs do not market the ISV's products or services directly, they help in the indirect technological upgradation of ISVs. According to an MNC representative,

'See, this (ISV program) is a voluntary effort. The idea is to reach more people through this program and encourage them to develop more products. It's up to the vendors to advertise the products and get it into the market. We help in the process. We help in marketing by providing a platform for their applications. We call them to our road shows. They can upload their stuff in our product brochures. On the technology side, we may not know what the product is, its design and architecture, etc. They come up with queries and specific questions, and we answer them. Sometimes they want to benchmark their products. They come to our premises and use facilities here, and we help them in doing that. We also help in migration from some other technologies to our technologies. In a few cases, we collaborate more deeply, help them in designing, sit with them in selecting tools, etc.'

Some firms are able to exploit the partnerships, due to their technological capabilities. One firm explained the process as below:

'Lending a hand doesn't mean they [MNCs] have to give [us] their technology. They give [show] their products and we need to know how to port ours. Our people get trained by them and you don't have to spend too much money on doing all that. They will help in providing the necessary hardware and systems. This is on the technology side. On the marketing side, the whole purpose of doing all this is to generate revenue for each other in the market place. For us, it is good, when a well known brand like an IBM or HP goes to the market and says hey there is this company called $\mathrm{XXX}^{\mathrm{d}}$ and they have very good insurance solutions. This IBM or HP may have a good relationship with an insurance company for a number of years by selling their other products. When it comes to kind of solutions that we have, they introduce us.'

Larger firms also use ISV programmes to extend their market reach. A large firm highlighted its relationship as below:

'We use Oracle in our products. We look for their support for any technical issues. We use them to get some international connections. For example, in New Zealand, we checked with Oracle, whether they had any link. They had it. So if they have links it can facilitate the sale. They will not make the sale for us, but make connections for us. They have an ISV partner relationship programme, and they conduct various meets (events) where they have Oracle folks coming in, so that you can get connected with the people. You get to meet people like the manager of the Indian international division, or let us say the telecom manager for the Asia Pacific region. We go and speak to him and get connected, so we have such opportunities.'

MNCs also have subcontracting relationships with large firms in the form of IDCs which serve as the offshore development centers. A large firm may serve many competing MNCs with several IDCs. However, they are bound by nondisclosure agreements, and rival IDCs for competing clients are not permitted to interact with each other. MNCs are also careful not to outsource projects that may benefit rival IDCs within the same domestic firm.

Interviews suggested that the linkages between MNCs and small firms were mostly vendor relationships. Small firms buy and use the technologies from MNCs for which post-sales support is provided. Although this relationship can be used as a signal to potential prospects in this domain, small firms reported that they were not confident about the benefits. To quote:

'We are allied to MSN and Oracle. They are more like technology partners. We use their technology and they provide us support. They don't really get into marketing for us, and neither do we use their marketing channels for our product. Sometimes they showcase our products in exhibitions or their websites. This is more to market their technologies rather than our products. Chances are there we might have got some business leads through that. But I would say that the chances are low.'

Some small firms use a different route to earn revenue through links with MNCs. They serve as resellers of the products of MNCs in the domestic market and in unexplored, small foreign markets (for instance, in the 
Middle East). This reselling mechanism is also used to enhance the value of their products. To quote:

'We collaborate with a CRM product company in US. We sell their products in India with the topping of our product and services. They have licensed to us. No more help from them. They are important to us. Not vice versa. They are global leaders. We are very small people to them. Their product does not have web enabled support. We give that.'

\section{The priorities of domestic firms and domestic bodyshopping}

When Indian firms receive projects from MNCs, they have an option of subcontracting to smaller firms unless sensitive R\&D services are outsourced. However, large firms, both the top 20 firms and those in our sample, prefer to execute the projects themselves. In doing so, they are following the strategy of Tata Consultancy Services (TCS), the oldest and largest domestic firm. According to one respondent:

'In India, large to small firm collaborations are limited. TCS never believed in it. Why do I have to train an unknown person who will become a competitor to me? Whatever may be the size of project, I will do it. Now a lot of Indian biggies follow it. They don't do it (sub-contract).'

The above response points to two reasons for the lack of inter-firm linkages. The worry about collaboration nurturing competition reflects the fear of losing clients, especially since most Indian firms are exploring the same market, i.e., exports to the USA. Small firms that tried to establish linkages with larger firms found them unwilling. To quote:

'Larger firms do not even respond. We tried a couple of meetings; we do not want to name the people. We tried meeting them and getting their ideas. What they say is, 'Oh he is traveling or he will come back, he is booked till August/September etc. etc.'

Indeed, as the representative of one large firm said, 'We do not sub contract to any small firms. We can ramp up very fast and there was no need for subcontracting. Our (workforce) utilization rate is around 73 \%.' The utilization rate refers to the proportion of employees deployed on projects. For the above firm, $27 \%$ of the workers are kept in reserve or, to industry parlance, 'on the bench', to be deployed in future projects.

Larger firms prefer to keep a bench workforce than subcontract to other firms because their business model is such that revenue generation is proportional to the number of people deployed. Profit margins are larger if more people can be deployed and projects are executed directly. Further, due to the brand premium of the larger firms in the market, they are able to attract quality manpower (engineering graduates from tier I educational institutions) at competitive salaries, thus maintaining quality of work at a relatively low cost. Small firms are not able to compete for the same labor pool without offering higher compensation and therefore tend to hire people from tier II educational institutions. This forces them to deploy more people to do similar work, and spend more money on training, which eventually affects their profit margins.

To the extent that local subcontracting takes place, it takes the form of domestic bodyshopping (euphemistically referred to as manpower consultancy services), rather than offsite execution. It involves small firms sending their programmers to the premises of large firms or on-site. This generates steady revenue even as direct market opportunities fluctuate. Since large domestic firms predominantly serve export markets, projects subcontracted to the small firms are from foreign clients; hence, it appears that small firms access global markets indirectly. To quote:

'We have our people working in the larger firms. But they do not come to our development center. But we send our people there. We have our people placed in different firms. We've placed our people on consulting work. We are also going through certain difficulties during the last two years, especially after September 11 . We are slowly concentrating on staffing practices. We are staffing partners for eleven multinational companies in India and abroad, where our people are working onsite on a consultation basis.'

Domestic bodyshopping happens informally and formally. Informally, programmers from small firms are sent to larger firms for short durations on the basis of personal requests rather than as a formal business arrangement. Here, revenue generation is secondary to doing a favor to friends or contacts in the industry. These informal relationships are common among small firms. To quote a small firm:

'We keep collaborating with larger players. For example we work with XXX (a top twenty firm) very closely. We have a set of friends, or groups we can say. We don't have hard documents to show. Personally we are in touch with each other. If anything comes up we come together. Those things are very common.' 
The prevalence of such linkages is reinforced by the comment of a larger player:

'We have an understanding with a few companies. For example, if we get a small project on a technology which I do not have, I can call up the people from my collaborators. I don't want to call them collaborators. It's a loose association with companies who are good in certain technologies. Most of them come through personal contacts.'

Among the formal arrangements, some small firms understand the inadequate learning opportunities and, therefore, limit the linkage. To quote:

'We have manpower consultancy relationships with a few of the larger firms. What they want is manpower supply not real collaborations. We did not find any value in that. If you look at the revenue generated it is important. We get around $20 \%$ of our total revenues from it. We are not interested in expanding this more. Though our growth is modest, we would like to keep [our growth] this way.'

The risks are also high for firms that participate in the body shopping in domains where they do not work. They need to hire people in order to supply the larger firms. Once the project is over, the contracted labor returns to the small firms, forcing them to find new projects and pay them for the non-work period, which can be expensive.

Small firms that have tried alliances with other small firms found that worries about encroaching into revenues a hindrance. To quote:

'We have worked with three partners till now. It's all small business. It does not move afterwards. They say "No, I should know with whom you are talking" They don't trust. I don't know why people should know what I am doing. I am saying I will give you ten rupees for this job. Fine. You should be happy and I am happy. If somebody comes and tells you today I will give you five rupees for this job, come with me. If five is OK for you then you should take it. Why should you bother what I do, whether I make ten or more. I don't care. Five is good for me. But people think "Oh why is he making ten rupees?" That has to change. We should not bother what the other man is making. You should be bothered about what you want to make. If you are getting, then be happy.'

\section{The survival strategies of small firms}

In the absence of inter-firm linkages to help them with global opportunities, almost all small firms start by executing contracts which originated from the founders' personal networks. This can be explained by the professional background of the entrepreneurs included in this study. Most of them worked in the USA in the early phases of their career, especially during the bodyshopping wave of the 1980s and the 1990s. Their firms tend to imitate the offerings of larger firms and would like to resemble them in the future. Their initial contracts were provided or outsourced by the people abroad with whom they networked during their earlier employment. One industry representative summarized it as below:

'I think most of the smaller firms survive through personal contacts. There is no vision or niche focus. They will do whatever comes their way and execute it. It is after sometime, when they become medium sized, that they start looking at a vision of what they want to be. They start looking at formal and professional business development activities. Till that time it is primarily personal contacts.'

In later stages, they employ various mechanisms to access the global market. These mechanisms include contracting to individuals or firms abroad as business associates or trade partners. These individuals or firms may be either acquaintances or formally recruited. Alternatively, firms may station a co-founder or establish a small marketing team abroad. To quote the founder of a small firm:

'We also make use of intermediaries (to get businesses). They are of two kinds. One is individuals. We know them for a long time. They work as referral advisors. Their job ends when they introduce prospective clients. When the deal works out, they get a commission. This is very frequently used. Second kind is organizations. We have tie-ups with them.

They would have very good market reach, but execution capacity is not there and they look for someone in India. We fill the gap. These organizations are small in size and founded by guys, sometimes Indians, who have been working onsite for long time. Some American companies are also there.'

The founder of a small firm narrated its growth as follows:

'My first set of customers came through personal contacts. The first came through a friend of mine. He was the CEO of a company. When we started the firm, we called up a lot of people. Tried to catch up with them. Went and met a lot of people. Gave presentations and provided references for our capabilities. The next project was from another friend. 
He was the CIO of a company. [A] reference from a first client helped in getting the next project. When business became stable, we hired marketing people in the USA, sales guys who have been working for the last 20 years. We looked for people who are experienced and have good contacts. After this, no more personal contacts to get business.'

In a few cases, business relationships are established through international trade fairs and conferences. To quote:

'We, first of all, find opportunities in these countries on the web, then try to contact them on phone or email to fix up appointments and go and meet them, wherever we don't have offices. Countries where we have our offices, like Japan and US, we ask our office people to meet them. Thereafter, it takes its own shape. We also go to exhibitions in these countries, national exhibitions, not setup by NASSCOM or ESC or anybody, [but] their own exhibitions, where lots of local companies come. We meet them, explain to them what we have and then build a contact.'

The transition from personal network-based marketing to other mechanisms is a major differentiator among small firms. Those who are able to generate business successfully from non-personal networks evolve in terms of the nature of services provided, revenue, and number of employees. As the firms advance, they acquire certain credentials like quality certifications, showcasing a local partner at foreign locations, and hiring local marketing to meet demands at the next level of business. Acquiring quality certificates such as those from the International Organization for Standardization's ISO 9000 series (International Organization for Standardization 2012) allows small firms to impress upon prospective clients that standardized processes are followed. The Software Engineering Institute's Capability Maturity Model Integration (Software Engineering Institute 2012) certification is preferred by larger firms, typically those with 150 employees and more, as the certification process is relatively expensive and requires a larger employee base.

\section{Conclusions}

The paper attempted to determine whether small software firms in India access global software markets through inter-firm linkages with MNCs and large domestic firms. This issue is especially pertinent given the growing number of small software firms which no longer have the options that were available until the mid-1990s, thanks to labor market pressures and rising wages.

Notwithstanding claims to the contrary, MNCs prefer alliances with large domestic firms rather than small firms. This reflects limited technological and organizational capabilities of small firms. They are mostly generic service providers rather than niche players and are unable to offer an attractive module or supplementary product to play the role of ISVs. The difficulties small firms have in partnering MNCs also reflect the context of outsourcing: the need for scale to cut costs for laborintensive services. Larger domestic firms have the means to deploy and manage a large number of people in IDCs. More employees allow large domestic firms to offer clients a wider range of technological and domain capabilities.

The need for scale in the business model of software service provision is also why larger domestic firms tend not to engage with smaller firms. Revenue generation is proportional to the number of people deployed, and profit margins are larger if more people can be deployed and projects are executed directly. Thus, the larger firms prefer independent execution and would rather keep employees on the bench than outsource work to small firms. The large domestic firms are also concerned about nurturing competition especially since small firms tend to imitate the offerings of larger firms and compete for the same markets. This only results in weak inter-firm linkages. Ironically, to the extent inter-firm linkages exist, through domestic bodyshopping, small firms attempt to limit them. At one level, this is because they do not want to be stuck with employees who may be hard to employ after they return from a project. At another level, it is because of a perceived lack of control over their alliances. Consequently, it is only if they can either prove their worth in terms of technological capabilities or manpower scaling can small Indian firms rely on large firms to act as intermediaries to access the global market. While such issues have long plagued small firms in India (Morris et al. 2001), the findings here suggest that their lot has not changed significantly despite the opportunities offered by ICTs.

Although India does not suffer from a lack of small firm formation, this paper shows the challenges it faces in the absence of intermediary institutions. On one hand, the lack of venture capital or the ability to hire the best talent limits the technological capabilities of small firms. On the other, the lack of scale leads to their being dwarfed by the large domestic firms that they would like to emulate, and to be ignored by MNCs establishing IDCs. In other words, in the custom software business, the large firms are not terribly helpful as intermediary institutions. Small firms then have to rely on the personal contacts of their founders as the first step to institutionalizing their relationships with global markets.

Despite the findings about the lack of intermediate institutions, the continued formation of small firms in India suggests not only perceived opportunities for growth but 
also directions for future work that can build on the findings presented in this paper. As a next step, for instance, it will be worth investigating how a cohort of firms founded in a given year fare over a certain time period and the intermediate institutions that they can either rely on, or they are denied the support of, as they either prosper or wither away.

\section{Methods}

\section{Defining small firms}

The definition of small firms varies widely by industry and by geographical region. For example, in the Netherlands, small firms employ less than 10; in the USA, 20 to 99; and in Italy, 200 (SIDBI 2000). Even within a country, adopting a generic definition of small firms can lead to inconsistent results due to differences in production functions across industries. Existing studies of small software firms do not address this definitional problem adequately (see for instance, Bell 1995; Coviello and Munro 1997). Across the studies, the definition of the small firm varies from 100 to 250 employees, which creates problems for generalization.

In India, the definitional problem persists despite the software sector being declared a thrust area for national growth. Under the broad framework of small-scale industries, which are defined as enterprises with an investment of up to 0.5 million Indian rupees in fixed assets (excluding land and building), software firms are listed under small-scale service and business (industry-related) enterprises and grouped with 'X-ray clinics' (SIDBI 2000, page 53).

Given the anomalies in the definition of small software firms, this study follows a 'working definition' rather than adopting an existing definition. A small software firm is defined as one that has fewer technical employees than the industry median. The median is preferred as the measure of central tendency than the mean, due to extreme variations in the sizes of firms. For instance, Infosys had around 30,000 employees while many firms employed barely 10 (NASSCOM 2004). Based on the data from the NASSCOM Directory 2003, firms with 73 or fewer technical employees are taken as small software firms. The rest are large firms. While adopting this definition, this study acknowledges that NASSCOM does not represent all firms in the industry and that the median firm size may well fluctuate over time.

\section{Sample}

All firms, with details of the number of employees and export revenue, listed in the NASSCOM (2004a) were contacted, and data were collected from those who volunteered for the study. Data were collected from 110 sample firms across six software clusters: Bangalore, Chennai, Hyderabad, Pune, Delhi, and Mumbai. Of the
110 firms, 60 are small firms as defined by the study with a median size of 36 employees, and 50 are large firms with a median size of 200 employees (see Table 1). In the sample, large firms are more heterogeneous than small firms as the standard deviation and the difference between mean and median values indicate. The study did not include the 20 largest firms by revenue in the survey, as their size, ranging from 10,000 to 50,000 employees, will distort the results. Our attempts to include a proportionate number of firms in various geographical regions to reflect the population of the NASSCOM Directory were not successful due to the refusal of many firms to participate in the study and the high mortality rate among firms. During the entire course of the project, the fieldwork was continued in Bangalore, where the researchers were based, resulting in a relatively larger number of interviews.

Data were collected through 'structured open-response interviews' (King 1994) which fall between a structured questionnaire with closed questions, and ethnographic interviews with a very low degree of structure imposed by the interviewers. Before each interview, relevant information about the firm, available from the trade press and the firms' websites, were gathered to tailor questions. For instance, rather than asking about foreign collaborations in general, the respondent was asked to explain the relationship that the firm shared with the firm $X$ as reported in the website. This provided the flexibility to gather the information for this study. While approaching the firms to collect data, respondents were assured of anonymity to enhance access and to gather information required for the study. Hence, the names of the respondents and firms are not identified in the paper.

Approximately $1 \mathrm{~h}$ was spent interviewing each respondent. In a few cases, interviews lasted for barely $20 \mathrm{~min}$ as respondents were reluctant speakers, whereas others lasted up to $3 \mathrm{~h}$. Except for four interviews, all interviews were conducted in person, and around $80 \%$ of the interviews were conducted with one of the founders or founding members of the sample firms. In-depth , semi-structured interviews were also conducted with 62 industry representatives who were not part of the sampling frame. Interviewees included representatives from various trade associations, the 20 largest firms, industry-specific voluntary organizations, and opinion leaders drawn from job portals, manpower consultants, the trade press, and academia. We also employed participant observation methods when attending four different events and panel discussions for software firms organized by trade associations. Fieldwork was conducted in two phases: October 2004 to February 2005 (Bangalore, Chennai, and Hyderabad) and September 2005 to January 2006 (Pune, Mumbai, and New Delhi). 
Table 1 Sample distribution by geographical region and size

\begin{tabular}{lcccccccc}
\hline Firms & Bangalore & Chennai & Hyderabad & Mumbai & Delhi region & Pune & $\begin{array}{c}\text { Mean } \\
\text { Meographical regions }\end{array}$ & $\begin{array}{c}\text { Size of the firm (number of technical } \\
\text { employees) } \\
\text { Median }\end{array}$ \\
$\begin{array}{l}\text { Standard } \\
\text { deviation }\end{array}$ \\
\hline $\begin{array}{l}\text { Small firms }<73 \\
\text { employees }(N=60)\end{array}$ & 20 & 4 & 5 & 10 & 16 & 5 & 36 & 33 \\
$\begin{array}{l}\text { Large firms }>73 \\
\text { employees }(N=50)\end{array}$ & 15 & 11 & 4 & 5 & 9 & 6 & 305 & 200 \\
\begin{tabular}{l} 
Total $(N=110)$ \\
\hline
\end{tabular} & 35 & 15 & 9 & 15 & 25 & 11 & 160 & 62 \\
\hline
\end{tabular}

The analysis of qualitative data was conducted using the software programme Weft (for more details, see Fenton 2006). Interview data were fed into the programme, and passages with interview codes were generated. Weft searches all the interview transcripts and collates passages according to the codes which are then used to understand the patterns. Codes, composed of keywords, are equivalent to themes used in qualitative research. Keywords were selected on the basis of literature reviews and interview experiences. For inter-firm linkages, the following words were used: partners, partnership, JV, alliance, associate, collaboration, subcontracting, intermediaries, linkage, consultant, marketing, cold calls, email, subcontracting, and inter-firm. Paragraphs extracted by Weft were read to understand the patterns. Fieldwork and data analysis were conducted by the first author.

\section{Endnotes}

The present paper is based on a research project funded by the Leverhulme Trust, London. While the complete findings of the project are presented in Parthasarathy and Ilavarasan (2007), this paper only discusses those that relate to small firms and their inter-firm lin-

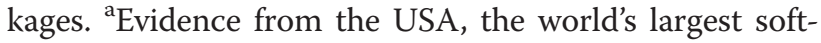
ware producer and consumer, shows that demand is met by new and small entrepreneurial firms (Egan 1997). To meet the growing demand, the number of product firms grew from 2,992 to 6,001 between 1987 and 1992. Although the number of firms more than doubled, the mean number of employees per firm went up from only 16.4 to 18.4, indicating that new firms were the ones taking advantage of market opportunities for mass-produced packaged software. Although these product firms accounted for $35 \%$ of output in the software industry, they accounted for barely $23 \%$ of the industry's employment, indicating higher productivity per employee. This productivity is higher than in software services, reflecting the increasing returns to scale of mass-produced packaged software. This conclusion is supported by Arora et al. (2007, page 3), who indicated that in the software product value chain, revenue generated by the third party firms that create custom software products for their customers employ more people and generate more revenue than the packaged software industry. It is most likely that these firms are small firms. ${ }^{\mathrm{b}}$ The latest firm-level data are available in the NASSCOM Directory. ${ }^{\circ}$ The H1-B classification enables employment up to 6 years in a specialty occupation which requires the theoretical and practical application of specialized knowledge requiring completion of a specific course of higher education. The L1 classification applies to intra-firm transferees who, within the 3 preceding years, were employed abroad continuously for 1 year, and who will be employed by a branch, parent, affiliate, or subsidiary of that same employer in the USA in a managerial, executive, or specialized knowledge capacity for up to 7 years (U.S. Citizenship and Immigration Services 2012). For immigration data, see U.S. Department of Homeland Security (2012). ${ }^{d}$ XXX is used to protect the identity of the company here. Throughout the paper, $X X X$, YYY, and ZZZ are used in multiple places to protect the identity of firms, products, and respondents.

\section{Competing interests}

The authors declare that they have no competing interests.

\section{Authors' contributions}

BP proposed the original idea, wrote the grant proposal, guided the study, and co-authored the manuscript. PVI developed the idea, developed the data collection tools, conducted the fieldwork, analyzed the data, and coauthored the manuscript. Both authors read and approved the final manuscript.

\section{Author details}

${ }^{1}$ Indian Institute of Managem ent Rohtak, MD Univ. Campus, Rohtak, Haryana 124 001, India. ${ }^{2}$ International Institute of Information Technology, 26/C Electronics City, Bangalore 560100, India.

Received: 7 February 2012 Accepted: 8 August 2012

Published: 8 August 2012

\section{References}

Acs, ZJ, Morck, RK, \& Yeung, B (2001). Entrepreneurship, globalization and public policy. Journal of International Management, 7(3), 236-251.

Aggarwal, BB (2002). Biggies of the future (Dataquest). http://dqindia.ciol.com/ content/industrymarket/newsanalysis/102091704.asp. Accessed 14 May 2004. Arora, A (2005). The emerging offshore software industries and the U.S. economy. Brookings Trade Forum, 399-409.

Arora, A, Gambardella, A, \& Torrisi, S (2001). In the footsteps of the Silicon Valley? (Indian and Irish software in the international division of labour (SIEPR Discussion Paper No. 00-41). Stanford Institute for Economic Policy Research.

Arora, A, Forman, C, \& Yoon, J (2007). Software. Sloan Industry Studies Annual Conference - 2007. Massachusetts Institute of Technology. web.mit.edu/sis07/ www/forman.pdf. Accessed 20 Dec 2008. 
Athreye, S (2002). Multinational firms and the evolution of the Indian software industry (SSRN). http://ssrn.com/abstract=361680. Accessed 17 Dec 2010.

Ayyagari, M, Beck, T, \& Demirguc-Kent, A (2007). Small and medium enterprises across the globe. Small Business Economics, 29, 415-434.

Ba, S, Whinston, AB, \& Zhang, H (2000). Small firms in the digital economy. In E. Brynjolfsson \& B. Kahin (Eds.), Understanding the digital economy (pp. 185-200). Cambridge: MIT Press.

Baetjer, H (1998). Software as capital-an economic perspective on software engineering. Washington: IEEE Press.

Balakrishnan, P (2006). Benign neglect or strategic intent? Contested lineage of Indian software industry. Economic and Political Weekly, 41(36), 3865-3873.

Balasubramanyam, A, \& Balasubramanyam, VN (1997). Singer, services and software. World Development, 25(11), 1857-1861.

Bell, J (1995). The internationalization of small computer software firms: a further challenge to "stage" theories. European Journal of Marketing, 29(8), 60-75.

Bell, L, Crick, D, \& Young, S (2004). Small firm internationalization and business strategy: an exploratory study of 'knowledge-intensive' and 'traditional' manufacturing firms in the UK. International Small Business Journal, 22(1), 23-56.

Bell, J, McNaughton, R, Young, S, \& Crick, D (2003). Towards an integrative model of small firm internationalization. Journal of International Entrepreneurship, 1 339-362.

Bennett, RJ, \& Ramsden, M (2007). The contribution of business associations to SMEs: strategy, bundling or reassurance? International Small Business Journal, 25(1), 49-76.

Casper, S, \& Whitley, R (2002). Managing competences in entrepreneurial technology firms: a comparative institutional analysis of Germany, Sweden and the UK (Working Paper 230). Cambridge: ESRC Centre for Business Research.

Castellani, D, \& Zanfei, A (2002). Multinational experience and the creation of linkages with local firms: evidence from the electronics industry. Cambridge Journal of Economics, 26, 1-25.

Chaminade, C, \& Vang, J (2008). Globalisation of knowledge production and regional innovation policy: supporting specialized hubs in the Bangalore software industry. Research Policy, 37(10), 1684-1696.

Chandrasekhar, CP (2008). IT in India: a turning point? (MACROSCAN) http://www.macroscan.org/cur/aug08/print/prnt090808IT.htm. Accessed 10 Jan 2009.

Coviello, NE, \& Munro, HJ (1997). Network relationships and the internationalization process of small software firms. International Business Review, 6(4), 114-135.

D' Costa, AP (2003). Uneven and combined development: understanding India's software exports. World Development, 31(1), 211-226.

Dataquest. (2012). DQ Top ten. http://dqtop20.dqindia.com. Accessed 4 April 2012.

Davis, CH, \& Sun, E. (2006). Business development capabilities in information technology SMEs in a regional economy: an exploratory study. The Journal of Technology Transfer, 31(1), 145-161.

Dossani, R, \& Kenny, M (2002). Creating an environment for venture capital in India. World Development, 30(22), 227-253.

Egan, EA (1997). The spatial dynamics of the US computer software industry. Ph.D. dissertation: University of California, Berkeley.

Economic Times (2011). IT majors Infosys, Wipro and TCS spawning new breed of entrepreneurs (Economic Times). http://economictimes.indiatimes.com/ opinion/india-emerging/it-majors-infosys-wipro-and-tcs-spawning-newbreed-of-entrepreneurs/articleshow/8173423.cms. Accessed 10 May 2012.

Commission, E (2010). Internationalisation of European SMEs. Brussels: DirectorateGeneral for Enterprise and Industry, European Commission.

Commission, E (2011). Are EU SMEs recovering from the crisis? (Annual Report on EU Small and Medium sized Enterprises 2010/2011). Cambridge: European Commission.

Fenton, A (2006). Weft_QDA_(version 1.0.1) [computer software]. http://www. pressure.to. Accessed 10 Jan 2009.

Srikanth, RP, \& Glancy, S (2003). Is Nasscom a 'big boys' club? (Express Computers). http://www.expresscomputeronline.com/20030217/cover.shtml. Accessed 15 June 2003.

Gomes-Casseres, B (1996). Alliance strategies of small firms. Small Business Economics, 9, 33-44

Heeks, RB, \& Nicholson, B (2002). Software export success factors and strategies in developing and transitional economies (Development Informatics Working Paper Series 12). University of Manchester. http://www.sed.manchester.ac.uk/idpm/ research/publications/wp/di/di_wp12.htm. Accessed 10 Jan 2010.
Infosys. (2012) http://www.infosys.com/pages/index.aspx. Accessed 10 March 2012.

International Organization for Standardization. (2012) http://www.iso.org/iso/ home/standards/management-standards/iso_9000.htm. Accessed 9 July 2012.

Kanavi, S (2004). Coming of age (Business India, 16-29 February) (pp. 55-58). http://reflections-shivanand.blogspot.in/2007_12_21_archive.html. Accessed 14 Mar 2012

Kennedy, A, \& Keeney, K (2009). Strategic partnerships and the internationalization process of software SMEs. Service Business, 3(3), 259-273.

King, N (1994). Using interviews in qualitative research inteview. In C. Cassell \& G. Symon (Eds.), Qualitative methods in organizational research: a practical guide (pp. 11-22). New Delhi: Sage.

Lerner, J (2000). Small business, innovation, and public policy in the IT industry. In E. Brynjolfsson \& B. Kahin (Eds.), Understanding the digital economy (pp. 201214). Cambridge: MIT Press.

Lindelof, P, \& Lofsten, H (2003). Science park location and new technology-based firms in Sweden: implications for strategy and performance. Small Business Economics, 20, 245-258.

McNaughton, RB (2002). The use of multiple export channels by small knowledge-intensive firms. International Marketing Review, 19(2), 190-203.

Morris, S, Basant, R, Das, K, Ramachandran, K, \& Koshy, A (2001). The growth and transformation of small firm in India. New Delhi: Oxford University Press.

NASSCOM. (2002). Small steps: NASSCOM now gets itself an SME focus. http:// www.financialexpress.com/news/small-steps-nasscom-now-gets-itself-an-smefocus/59458/. Accessed 7 Oct 2002.

NASSCOM. (2004). Indian IT software services annual directory. New Delhi: NASSCOM.

NASSCOM. (2012a). Indian IT-BPO Industry. http://www.nasscom.org/indian-itbpoindustry. Accessed 10 May 2012.

NASSCOM. (2012b). Vision and Mission. http://www.nasscom.org/vision-andmission. Accessed 20 May 2012.

OECD. (2002). OECD Information technology outlook: ICTs and the information economy. Paris: OECD.

Ojala, A (2009). Internationalization of knowledge-intensive SMEs: the role of network relationships in the entry to a psychically distant market. International Business Review, 18(1), 50-59.

Parthasarathy, B (2004). India's Silicon Valley or Silicon Valley's India? Socially embedding the computer software industry in Bangalore. International Journal of Urban and Regional Research, 28(3), 664-685.

Parthasarathy, B (2010). The computer software industry as a vehicle of late industrialization: lessons from the Indian case. Journal of the Asia-Pacific Economy, 15(3), 247-270.

Parthasarathy, B, \& Aoyama, Y (2006). From software services to R\&D services: local entrepreneurship in the software industry in Bangalore, India. Environment and Planning A, 38(7), 1269-1285.

Parthasarathy, B, \& Ilavarasan, PV (2007). Small ICT firms in developing countries: an analytical case study of India. International Institute of Information Technology Bangalore: Research Project Report.

Patibandla, M, \& Petersen, B (2002). Role of transnational corporations in the evolution of a high-tech industry: the case of India's software industry. World Development, 30(9), 1561-1577.

Prashantham, S, \& McNaughton, RB (2006). Facilitation of links between multinational subsidiaries and SMEs: the Scottish Technology and Collaboration (STAC) initiative. International Business Review, 15(5), 447-462.

Rasmus, L, \& Hesbjerg, B (2003). The virtual extension: a search for collective efficiency in the software cluster in Bangalore. Roskilde: Roskilde University.

Saxenian, A (2006). The new argonauts: regional advantage in a global economy. Cambridge: Harvard University Press.

SIDBI. (2000). SIDBI Report on SSIs. Lucknow: Small Industries Development Bank of India.

Software Engineering Institute. (2012). http://www.sei.cmu.edu/cmmi/index.cfm. Accessed 9 July 2012.

Teubal, M (2002). The Indian software industry from an Israeli perspective. Science Technology \& Society, 7(1), 151-186.

Torres, AM, \& Murray, JA (2003). The role of networks in venture creation among Irish software firms. Irish Marketing Review, 16(1), 5-14.

U.S. Citizenship and Immigration Services. (2012). http://www.uscis.gov/portal/ site/uscis/menuitem.eb1d4c2a3e5b9ac89243c6a7543f6d1a/?vgnextoid=a39e 901 bf9873210VgnVCM100000082ca60aRCRD\&vgnextchannel=a39e901b f9873210VgnVCM100000082ca60aRCRD. Accessed 9 July 2012. 
U.S. Department of Homeland Security. (2012). Yearbook of Immigration Statistics, various years. http://www.dhs.gov/files/statistics/data/. Accessed 9 July 2012. Vang, J, \& Ashiem, B (2006). Regions, absorptive capacity and strategic coupling with high-tech TNCs: lessons from India and China. Science, Technology \& Society, 11(1), 39-66.

Vishwanathan, V (2001). Wipro's offsprings. Business World, 38-48.

Yli-Renko, EA, \& Tontti, V (2002). Social capital, knowledge, and the international growth of technology-based new firms. International Business Review, 11, 279-304.

doi:10.1186/2192-5372-1-4

Cite this article as: llavarasan and Parthasarathy: Limited growth opportunities amidst opportunities for growth: an empirical study of the inter-firm linkages of small software firms in India. Journal of Innovation and Entrepreneurship 2012 1:4.

Submit your manuscript to a SpringerOpen ${ }^{\circ}$ journal and benefit from:

- Convenient online submission

- Rigorous peer review

- Immediate publication on acceptance

- Open access: articles freely available online

- High visibility within the field

- Retaining the copyright to your article

Submit your next manuscript at $>$ springeropen.com 